Document downloaded from:

http://hdl.handle.net/10251/151087

This paper must be cited as:

Gimenez, JB.; Aguado García, D.; Bouzas, A.; Ferrer, J.; Seco Torrecillas, A. (2017). Use of rumen microorganisms to boost the anaerobic biodegradability of microalgae. Algal Research. 24:309-316. https://doi.org/10.1016/j.algal.2017.04.003

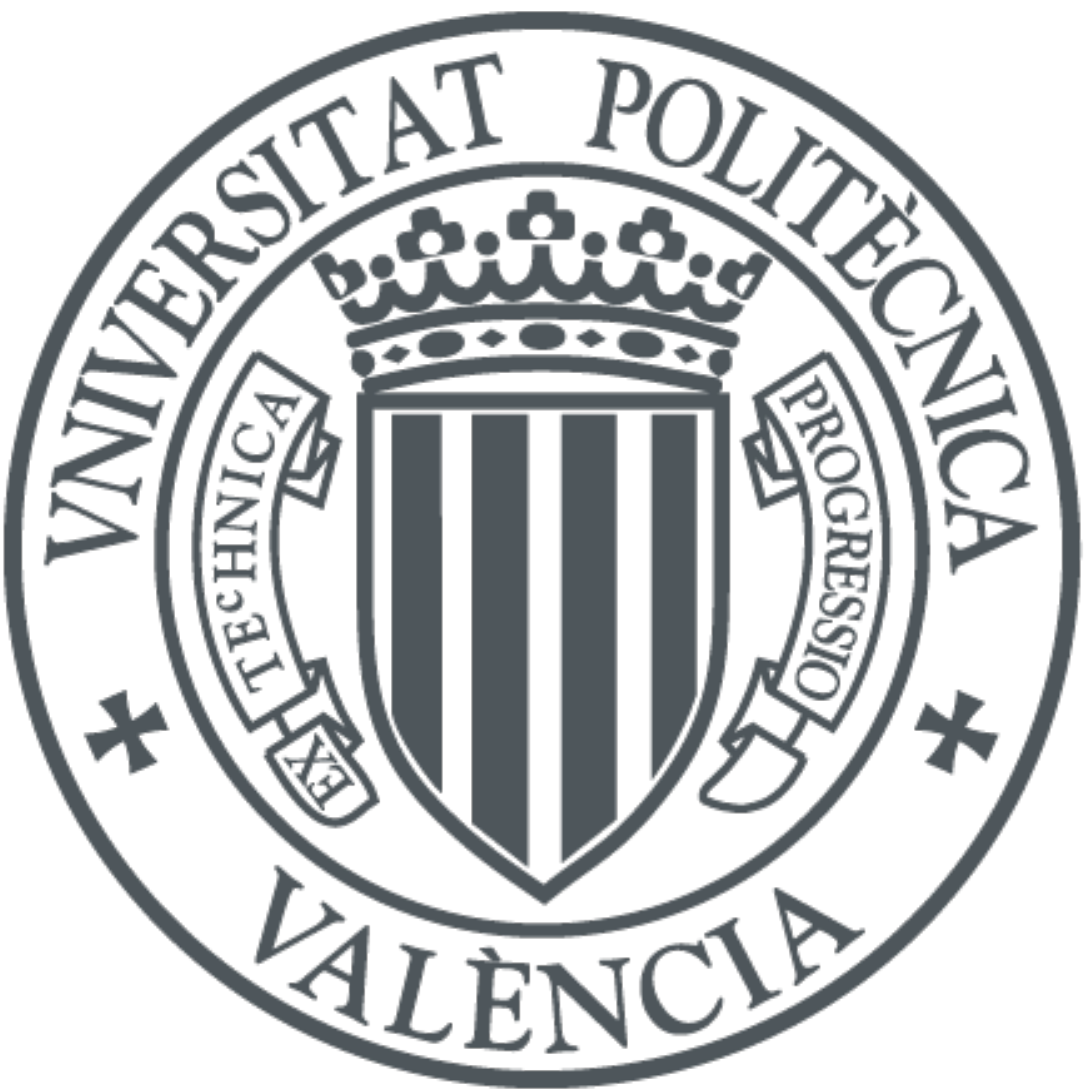

The final publication is available at

https://doi.org/10.1016/j.algal.2017.04.003

Copyright Elsevier

Additional Information 


\title{
Use of rumen microorganisms to boost the anaerobic biodegradability of microalgae
}

Juan B. Giménez ${ }^{\mathrm{a}, \dagger}$, Daniel Aguado ${ }^{\mathrm{b}}$, Alberto Bouzas ${ }^{\mathrm{a}}$, José Ferrer ${ }^{\mathrm{b}}$ and Aurora Seco ${ }^{\mathrm{a}}$.

${ }^{a}$ CALAGUA - Unidad Mixta UV-UPV, Departament d'Enginyeria Química, Universitat de València, Avinguda de la Universitat s/n, 46100 Burjassot, Valencia, Spain. (juan.b.gimenez@uv.es; alberto.bouzas@uv.es; aurora.seco@uv.es).

${ }^{\mathrm{b}}$ CALAGUA - Unidad Mixta UV-UPV, Institut Universitari d'Investigació d'Enginyeria de l'Aigua i Medi Ambient - IIAMA, Universitat Politècnica de Valencia, Camí de Vera s/n, 46022 Valencia, Spain. (ㅁaaggar@hma.upv.es; jferrer@hma.upv.es).

\begin{abstract}
A laboratory bioreactor using rumen microorganisms to treat Scenedesmus Spp biomass was operated for 190 days. At first the bioreactor operated as a Rumen-like Fermenter (RF) with a Sludge Retention Time (SRT) of 7 days. The RF was subsequently transformed into an anaerobic digestion system including two configurations: continuously-stirred tank reactor and anaerobic membrane bioreactor in which different SRT values of up to 100 days were assessed. Methane production peaked at $214 \mathrm{~mL} \mathrm{CH}_{4} \mathrm{~g}^{-1} \mathrm{COD}_{\text {In }}$ with a SRT of 100 days. COD removal and BDP peaked at above $70 \%$ and $60 \%$, respectively, at the highest SRT, with no pre-treatment
\end{abstract}

† Corresponding author. Tel.: +34 963543 085; e-mail: juan.b.gimenez@uv.es 
prior to microalgae digestion. The waste sludge production dropped to $0.133 \mathrm{mg}$ VSS $\mathrm{mg}^{-1} \mathrm{COD}_{\text {In }}$ after a SRT of 100 days.

Keywords: Rumen microorganisms; microalgae; AnMBR; waste sludge production; biodegradability potential.

\section{INTRODUCTION}

Microalgae biomass is an attractive feedstock for biofuel production for several reasons: they grow faster and have a higher biomass production than terrestrial crops and they can grow using wastewater as a medium [1]. Microalgae cultivation as a standalone treatment in photo-bioreactors or combined with activated sludge bacteria can be used in different phases of the wastewater treatment cycle depending on the nutrient composition of the wastewater [2]. In addition, the microalgae can use the $\mathrm{CO}_{2}$ in the flue gases of combustion engines as a source of carbon. This helps reduce the carbon footprint of the biofuels obtained from the microalgae [3].

Microalgae can be used to produce different types of biofuels and by-products, including the increasingly attractive methane generated by Anaerobic Digestion (AD). The main reasons are that microalgae biomass enables wet $\mathrm{AD}[4]$, and all the macromolecules (i.e. proteins, carbohydrates and lipids) found in microalgae can theoretically be transformed into biogas after AD [1]. In addition, because some of the nutrients in organic form are mineralized during $\mathrm{AD}$, they can be reused to cultivate new biomass ([5-8]).

The factor that influences the anaerobic biodegradability of microalgae most is cell wall composition. Sialve et al. [6] proposed a stoichiometric equation to predict the specific methane yield of a substrate with a known composition. The cell wall of some microalgae species, however, consists of complex carbohydrates with slow biodegradability and/or low bioavailability $([9,10])$. Such resilient cell walls hinder the 
digestion process because the organic matter retained in the cytoplasm is not easily accessible to anaerobic microorganisms [11]. The composition of the cell wall varies according to the species. Microalgae consist mainly of 25-30\% cellulose, $15-25 \%$ hemicellulose, $35 \%$ pectin and 5-10\% glycoproteins. Some species, such as Dunaliella salina, have no cell wall, whilst in others, the cell wall consists of glycoproteins (e.g. Chlamydomonas sp., Euglena sp. and Tetraselmis sp.), where AD is most effective (i.e. a high rate of biomass conversion) $([9,11])$.In contrast, $\mathrm{AD}$ of some other microalgae species (e.g. Chlorella sp., Nannochloropsis sp. and Scenedesmus sp.) with cellulosebased cell walls and containing sporopollenin and polyterpene, is hampered due to their recalcitrant nature $([9,11])$. As a result, the cell walls must be broken down in order to release the organic compounds inside the cells into the surrounding culture medium and make them accessible to the microorganisms outside. This increases the digestibility of the microalgae by the anaerobic microorganisms. A variety of technologies can be used to break down cell walls: thermal, mechanical, chemical or biological. Thermal pretreatments are the most widely used $([12,13])$, and their effectiveness depends on the strain of microalgae. Unlike thermal pre-treatment, the effectiveness of mechanical pretreatment does not depend on the characteristics of the microalgae species, although it is more energy intensive than thermal pre-treatment [14]. Chemical pre-treatments have been proven to be highly efficient, especially when combined with heat [15]. However, the presence of residual chemicals hinders downstream biological operations due to their toxicity [16]. Biological pre-treatments (i.e. enzymatic hydrolysis of the cell wall) increase the biodegradability of the microalgae whilst using little energy and employ operating conditions that are not very harsh [17]. In this context, the enzymatic hydrolysis of microalgae complex cell wall may be a promising alternative to energy- 
intensive mechanical and thermal pre-treatments and chemical hydrolysis because of its more favourable energy balance: a crucial factor for full-scale implementation.

In spite of studies regarding the effect of enzymatic hydrolysis of microalgae over the subsequent anaerobic digestion are scarce $([18,19])$, it seems reasonable to state that the overall cost of enzymatic pretreatment of microalgae may be lower than that of thermochemical hydrolysis, since the energy expenses related to the biomass heating are avoided. Operating in less demanding conditions enables standard equipment to be used, resulting in a lower capital outlay. Similarly, enzymes can be produced by a wide range of bacteria and fungi $([19,20])$.

For instance, several anaerobic microbial ecosystems, such as the digestive tract of termites and the rumen of ruminants, are very active in the conversion of lignocellulosic materials [21]. The controlled environmental conditions of rumen facilitate the growth of an extensive and complex microbial population which consists mainly of bacteria, many ciliate protozoa not found elsewhere in nature, flagellates and phycomycete fungi which are firmly attached to the solid substrate during degradation [21]. The physical coupling of the microorganisms to the substrate enables them to maximise their hydrolytic enzyme activities. In addition, the attachment of microbial cells to the solid digesta causes microbial biomass to be retained longer in the rumen, because the solid residence time has been shown to be much longer than the hydraulic retention time [21]. In artificial fermentation systems, biomass retention is achieved mainly by filtering techniques. In this regard, membrane bioreactors can be useful for retaining microorganisms whilst enabling a high quality effluent to be obtained. Some research involving biomass retention $([21,22])$ has demonstrated highly effective degradation of Neutral Detergent Fibres (NDF) with Sludge Retention Times (SRTs) as short as 3 or 4 days, and Hydraulic Retention Times (HRTs) of 12 to 18 hours. Longer HRTs 
decreased the degradation of NDF, probably due to the lower $\mathrm{pH}$ values caused by the accumulation of fermentation acidic end-products. Low $\mathrm{pH}$ values have been proven to affect "in vivo" and "in vitro" rumen fermentation negatively [21]. The way in which plant polymers are fermented by the microbial community in the rumen is comparable to the pattern observed in anaerobic digesters, but the acetate produced from Volatile Fatty Acids (VFAs) and the acetoclastic methane generated are far lower in the rumen because methane production reduces the potential substrate energy available for the animal. The use of rumen microorganisms in a rumen-like fermentation system might enhance the biodegradability of microalgae. However, the long-term cultivation of rumen microorganisms using artificial rumen in a simple, user-friendly construction is essential for such a purpose. Although rumen microorganisms have been used successfully in experiments to degrade lignocellulosic compounds including agricultural residues, the organic fraction of the municipal solid wastes and aquatic plants ([22-25]), rumen microorganisms have never been used, to the best of authors' knowledge, to digest microalgae anaerobically. Although most of the studies involving pre-treated biomass have been conducted in batch reactors, some long-term studies have already been undertaken in continuous digesters with SRTs ranging from 14 to 120 days [11].

The paper herein describes a simple, long-term, continuous system in which rumen microorganisms are used to degrade microalgae anaerobically. The effectiveness of the process is evaluated in terms of Chemical Oxygen Demand (COD) removal, Volatile Suspended Solids (VSS) removal, Waste Sludge Production (WSP) and BioDegradability Potential (BDP). The impact of SRT on reactor performance, using microalgae as substrate, is assessed.

\section{MATERIALS AND METHODS}

\subsection{Source of microalgae}


Microalgae were obtained from a pilot-scale membrane photo-bioreactor fed with nutrient-rich effluent from a pilot-scale, Anaerobic-Membrane BioReactor (AnMBR) treating municipal wastewater. Further details of the AnMBR pilot-scale plant can be found in [26]. Both pilot-scale plants are Calagua research group property and are located at the Barranco del Carraixet Wastewater Treatment Plant (Valencia, Spain). Before being fed into the acidogenic reactor, the collected microalgae were concentrated from 300 to $6000 \mathrm{mg} \mathrm{COD} \mathrm{L}^{-1}$ on average, in a Cross-Flow, Ultrafiltration Hollow-Fibre, (CF-UHF) membrane unit (Koch Romicon 2", 250kDa MWCO). Once the COD concentration was adjusted to the desired value, the microalgae biomass was characterised. The microalgae biomass consisted mainly of Scenedesmus Sp. (>90\%) except during an episode of cyanobacteria blooming around day 110 not taken into account when calculating plant performance. After being concentrated, the microalgae feedstock was stored at $4{ }^{\circ} \mathrm{C}$ for an average of 2 weeks depending on the original concentration of the microalgal liquor. Table 1 shows the average characteristics of the microalgae feedstock entering the anaerobic digester.

Table 1. Average characterisation of microalgae feedstock. Mean values \pm Standard deviation (SD) for the whole period $(n=28)$.

\begin{tabular}{ccc}
\hline Parameter & Units & Mean \pm SD \\
\hline T-COD & $\mathrm{mg} \mathrm{COD} \mathrm{L}^{-1}$ & $6093 \pm 350$ \\
S-COD & $\mathrm{mg} \mathrm{COD} \mathrm{L}^{-1}$ & $235 \pm 141$ \\
TS & $\mathrm{mg} \mathrm{TS} \mathrm{L}^{-1}$ & $5274 \pm 324$ \\
$\%$ VS & $\%$ & $75.4 \pm 5.2$ \\
TSS & $\mathrm{mg} \mathrm{TSS} \mathrm{L}^{-1}$ & $4201 \pm 383$ \\
$\%$ VSS & $\%$ & $91.0 \pm 3.3$ \\
T-N & $\mathrm{mg} \mathrm{N} \mathrm{L}^{-1}$ & $362 \pm 67$ \\
T-P & $\mathrm{mg} \mathrm{P} \mathrm{L} \mathrm{L}^{-1}$ & $71.8 \pm 17.9$ \\
\hline
\end{tabular}




\begin{tabular}{ccc}
\hline $\mathrm{NH}_{4}-\mathrm{N}$ & $\mathrm{mg} \mathrm{N} \mathrm{L}^{-1}$ & $43.5 \pm 24.7$ \\
$\mathrm{PO}_{4}-\mathrm{P}$ & $\mathrm{mg} \mathrm{P} \mathrm{L}^{-1}$ & $7.7 \pm 6.9$ \\
$\mathrm{SO}_{4}-\mathrm{S}$ & $\mathrm{mg} \mathrm{S} \mathrm{L}^{-1}$ & $91.6 \pm 25.8$ \\
$\mathrm{VFA}$ & $\mathrm{mg} \mathrm{CH}_{3} \mathrm{COOH} \mathrm{L}^{-1}$ & $159.5 \pm 111.9$ \\
$\mathrm{Alk}$ & $\mathrm{mg} \mathrm{CaCO}_{3} \mathrm{~L}^{-1}$ & $361.6 \pm 91.7$ \\
\hline
\end{tabular}

\subsection{Source of rumen microorganisms}

The rumen microorganisms used in this study were obtained from ruminal fluid extracted from a goat's rumen via the oesophagus and immediately transferred to a preheated, isolated flask. The ruminal fluid was strained through gauze to remove any coarse materials prior to inoculation.

The rumen ecosystem in goats is characterised by an almost constant supply of plant material, saliva and water, a constant temperature of $39^{\circ} \mathrm{C}$, an almost neutral $\mathrm{pH}$ (6-7), a low oxidation-reduction potential, and a higher removal rate of liquids than solids. These conditions favour the growth of a large and complex microbial population able to transform structural plant fibres [21].

\subsection{Experimental set-up.}

The experimental set-up consisted of two continuously stirred anaerobic reactors: a 7-litre rumen-like fermenter (RF; 4-litre headspace) and a 13-litre Anaerobic Reactor (AnR; 4-litre headspace). Figure 1a shows the lay-out of the RF, and the AnR. The RF had the same configuration than the RAn, the only difference being the volume of the reactor. The AnR became an anaerobic membrane bioreactor (AnMBR) after being fitted with an external UHF membrane module. Figure $1 \mathrm{~b}$ shows the lay-out of the AnMBR, consisting of the same AnR but with the addition of a membrane. 


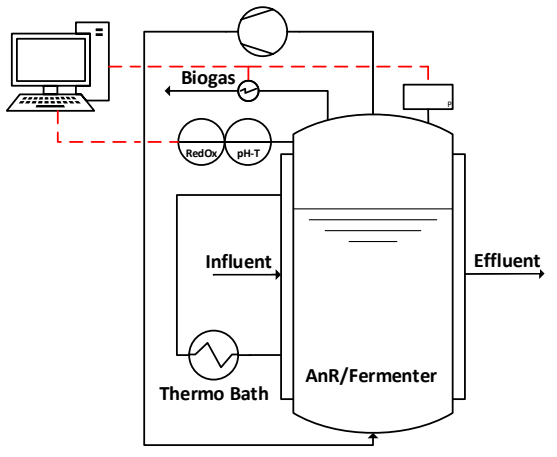

a)

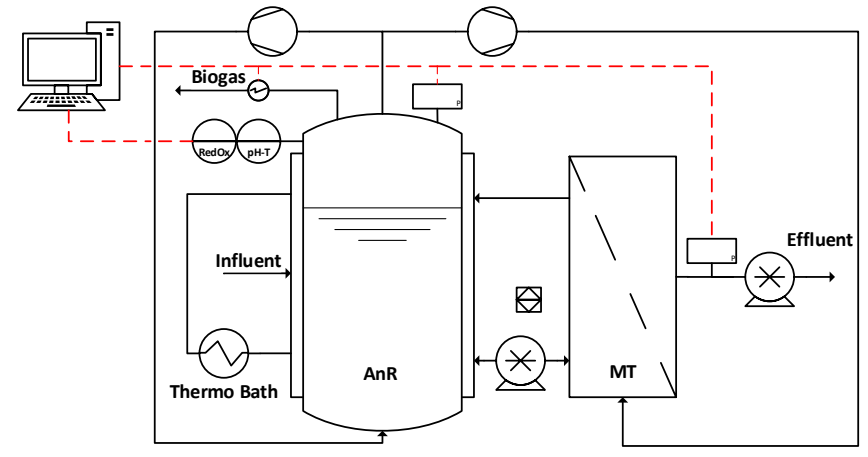

b)

Figure 1. Lay-out of the rumen-like fermenter and the anaerobic reactor (a), and anaerobic membrane bioreactor (b). AnR: Anaerobic Reactor; MT: Membrane Tank.

The temperature was kept at $38^{\circ} \mathrm{C}$ by a thermostatic water bath. The $\mathrm{pH}, \mathrm{RedOx}$ potential and headspace pressure were also monitored. Whilst operating as an AnMBR, the pressure on the permeate side was also monitored in order to calculate the transmembrane pressure.

\subsection{Experimental procedure}

In this study, five different sets of operating conditions were applied. Table 2 shows the operating conditions in each period. The reactor was fed once a day every weekday. The average weekly Organic Loading Rate (OLR) was calculated.

Table 2. Operating conditions set in each period.

\begin{tabular}{cccccc}
\hline Run & Period & Operating days & SRT & HRT & OLR \\
& & & $d$ & $d$ & $\boldsymbol{g}$ COD L $\mathbf{L}^{-1} \boldsymbol{d}^{-1}$ \\
\hline I & I & $0-40$ & 7 & 7 & $0.3-2.62$ \\
II & II & $0-14$ & 14 & 14 & 0.4 \\
& III & $15-64$ & 28 & 28 & 0.2 \\
& IV & $65-134$ & 70 & 31 & 0.2 \\
& V & $135-190$ & 100 & 31 & 0.2 \\
\hline
\end{tabular}


The start-up period spanned the first 40 days (Run I, Period I), during which time the system was operated in RF mode. The aim was to pre-treat the microalgae biomass in order to increase its biodegradability. At first, a retention time of 7 days $(\mathrm{HRT}=\mathrm{SRT})$ was set for the RF, and the OLR was increased step by step from 0.3 to $2.62 \mathrm{~g} \mathrm{COD} \mathrm{L}^{-1} \mathrm{~d}^{-1}$. Run II included periods II to $\mathrm{V}$, during which time the system operated as an AnR for the direct digestion of microalgae biomass. RF sludge was used as an inoculum for the AnR. At first, the AnR was filled 2/3 full with RF waste sludge for a period of 14 days during which time no sludge was removed. At this point, the RF system was stopped and the RF sludge (3 litres) was transferred to the AnR, topping up the 9-litre anaerobic reactor volume completely. During run II, the T-COD concentration of microalgae biomass was set to $6 \mathrm{~g} \mathrm{~L}^{-1}$, and the OLR varied depending on the HRT, which was the same as the SRT in the periods when the system operated without membranes. In period II, the retention time was set at 14 days (i.e. HRT = SRT), resulting in an OLR of $0.4 \mathrm{~g} \mathrm{COD} \mathrm{L}^{-1} \mathrm{~d}^{-1}$. The OLR of period III was half $(0.2 \mathrm{~g}$ COD L $\mathrm{L}^{-1} \mathrm{~d}^{-1}$ ) of that from period II as a result of doubling the retention time (28 days). In period IV, the system was transformed into an AnMBR by the addition of an external UHF membrane module (PURON Koch membrane systems, $0.05 \mu \mathrm{m}$ pore size). This enabled SRT to be dissociated from HRT and increased to 70 days, whilst HRT and OLR were kept at their previous values. HRT in period III (28 days) differs slightly from those in periods IV and V (31 days) because the system volume increased from 9 to 9.9 litres after the membrane was added (the volume of the membrane module was 0.9 litres) whilst the influent flow rate remained constant. In period V, the SRT was increased to 100 days.

Following every change in the operating conditions, the system was allowed to evolve until a steady state was achieved, which was characterized by a negligible T- 
COD accumulation and a stable biogas production. Once the steady state was achieved, the system performance was evaluated in terms of COD removal, VSS removal, WSP and BDP on a weekly basis.

\subsection{Biogas production and characteristics}

Daily biogas production was measured by means of a $\mu$ flow ${ }^{\circledR}$ gas flow meter (Bioprocess Control). Biogas from the reactor headspace was sampled three times a week. The biogas methane content was measured using a Gas Chromatograph fitted with a Flame Ionization Detector (GC-FID, Agilent Technologies). $0.25 \mathrm{ml}$ of biogas were collected from a sampling point connected to the top of the reactor by a gas-tight syringe and injected into a $15 \mathrm{~m} \times 0.53 \mathrm{~mm} \times 1 \mu \mathrm{m}$ TRACER column (Teknokroma) which was maintained at $40{ }^{\circ} \mathrm{C}$. Helium was used as the carrier gas at a flow rate of $5 \mathrm{~mL} \mathrm{~min}^{-}$ 1. Pure methane gas (99.99\%; Air Products Inc.) was used as standard.

\subsection{Analytical methods}

Samples from effluent and anaerobic sludge from the reactor were collected once a day. Total Solids (TS), Volatile Solids (VS), Volatile Fatty Acids (VFA) and Alkalinity (Alk) were analysed in triplicate three times a week. Total and Soluble COD (T-COD and S-COD, respectively), Total Suspended Solids (TSS), Volatile Suspended Solids (VSS), Ammonium ( $\left.\mathrm{NH}_{4}-\mathrm{N}\right)$, Phosphate $\left(\mathrm{PO}_{4}-\mathrm{P}\right)$, and Sulphate $\left(\mathrm{SO}_{4}-\mathrm{S}\right)$ were determined once in a week also in triplicate. All the analyses were performed according to Standard Methods [27], except for carbonate alkalinity and VFA concentrations which were determined by titration pursuant to the method recommended by the South African Water Research Commission [28].

\subsection{Calculations.}


BioMethane potential (BMP) was calculated as methane COD over total influent COD (Equation 1), and BDP was calculated as by-product COD (i.e. methane plus sulphide) over total influent COD (Equation 2, adapted from [29]):

$$
\begin{array}{cc}
\mathrm{BMP}(\%)=\mathrm{CH}_{4}-\mathrm{COD} / \mathrm{COD} \text { Influent }^{*} 100 & \text { Equation 1 } \\
\mathrm{BDP}(\%)=\left(\mathrm{CH}_{4}-\mathrm{COD}+\mathrm{H}_{2} \mathrm{~S}-\mathrm{COD}\right) / \mathrm{COD}_{\text {Influent }} * 100 & \text { Equation 2 }
\end{array}
$$

where $\mathrm{CH}_{4}-\mathrm{COD}$ is the COD of the methane generated (methane dissolved and in biogas), $\mathrm{H}_{2} \mathrm{~S}-\mathrm{COD}$ is the COD consumed during the dissimilative sulphate reduction to sulphide, and $\mathrm{COD}_{\text {Influent }}$ is the $\mathrm{COD}$ of the influent.

\subsection{Statistical analysis.}

Analysis of variance (ANOVA) was conducted to determine whether there was any significant difference in the mean values obtained for the selected parameters whilst operating the system for different SRTs. The mean values were considered to be different when the $p$-value was lower than the significance level $(\alpha=0.05)$. Differences between pairs of values were analysed using Fisher's Least Significant Difference (LSD) intervals. All statistical tests were performed using Statgraphics® (Statpoint Technologies Inc., Warrenton, Virginia) and Microsoft Excel@ (Microsoft Corporation, Redmond, Washington).

\section{RESULTS AND DISCUSSION.}

\subsection{Run I: Biological pre-treatment of microalgae biomass using rumen microorganisms. Start-up of rumen-like fermentation system.}

The system began as a rumen-like fermenter (RF) for the pre-treatment of microalgae biomass. In this study, a 40-day fermentation period was evaluated. In the absence of a biomass retention system, a 7-day retention time $(\mathrm{HRT}=\mathrm{SRT})$ was used during fermentation to ensure that the microorganisms would be retained. Figure $2 \mathrm{a}$ 
shows influent T-COD and S-COD, and also the evolution in OLR during the start-up period. Initially, an OLR of $0.3 \mathrm{~g}$ COD L ${ }^{-1} \mathrm{~d}^{-1}$ was selected to prevent RF failure whilst the biomass was acclimatising to the new substrate. The OLR was then increased step by step from 0.3 to $2.62 \mathrm{~g} \mathrm{COD} \mathrm{L}^{-1} \mathrm{~d}^{-1}$ by modifying the influent COD. The final OLR was still lower than in other studies (10-35 $\left.\mathrm{g} \mathrm{VS} \mathrm{L}^{-1} \mathrm{~d}^{-1}\right)$ to prevent the RF acidification during long HRT (7 days) reported by Gijzen [21].

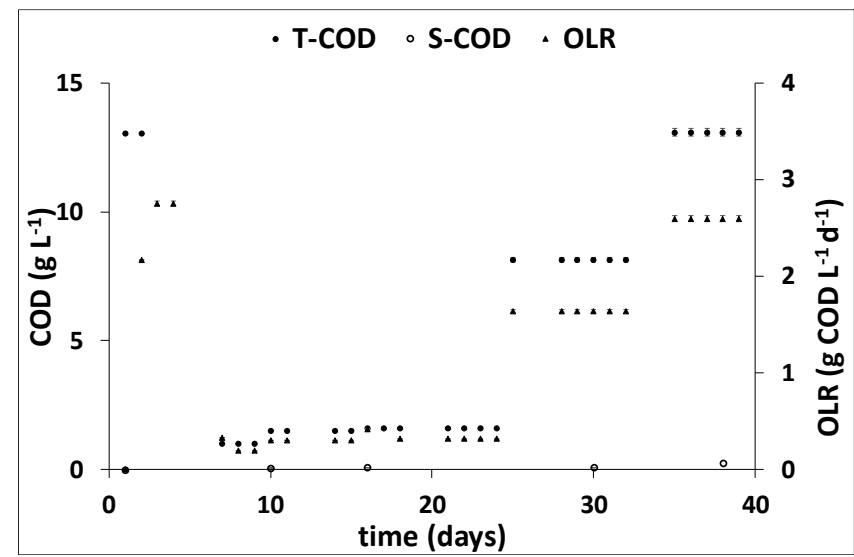

Figure 2. Influent T-COD and S-COD, and organic loading rate (OLR). Error bars represent the standard deviations of the average values determined from three measurements.

Figure $3 a$ shows the evolution of VFA and alkalinity in the RF, and Figure $3 b$ shows the evolution of daily methane production in terms of $\mathrm{CH}_{4}$ volume. A steady VFA concentration of some $75 \mathrm{mg} \mathrm{CH}_{3} \mathrm{COOH} \mathrm{L}^{-1}$ was achieved after operating the RF for 20 days (see Figure 3a). The biogas production was negligible for the first 26 days of operation (OLR $\left.=0.3 \mathrm{~g} \mathrm{COD} \mathrm{L}^{-1} \mathrm{~d}^{-1}\right)$, but biogas equivalent to approximately $0.28 \mathrm{~g}$ $\mathrm{COD} \mathrm{d}^{-1}$ was produced after the influent COD increased from 1.6 to $8.2 \mathrm{~g} \mathrm{COD} \mathrm{L}^{-1}$ (see Figure $3 b$ ), causing OLR to climb from 0.3 to $1.6 \mathrm{~g} \mathrm{COD} \mathrm{L}^{-1} \mathrm{~d}^{-1}$ (see Figure 2). VFA fell from 75 to $18 \mathrm{mg} \mathrm{CH}_{3} \mathrm{COOH} \mathrm{L} \mathrm{L}^{-1}$ as biogas production increased from day 27 onwards (see Figure 3a). A further increase in influent COD to $13.1 \mathrm{~g} \mathrm{COD} \mathrm{L}^{-1}$ from day 35 onwards caused OLR to climb to $2.62 \mathrm{~g} \mathrm{COD} \mathrm{L}^{-1} \mathrm{~d}^{-1}$ (see Figure 2). VFA rose to $200 \mathrm{mg} \mathrm{CH}_{3} \mathrm{COOH} \mathrm{L}^{-1}$ following the OLR increase (see Figure 3a). Biogas production 
also rose to around $0.9 \mathrm{~g} \mathrm{COD} \mathrm{d}^{-1}$ following the OLR increase (see Figure $3 \mathrm{~b}$ ), the equivalent of approximately $10 \%$ of the affluent COD (approximately $10 \%$ of the influent COD was transformed into methane).

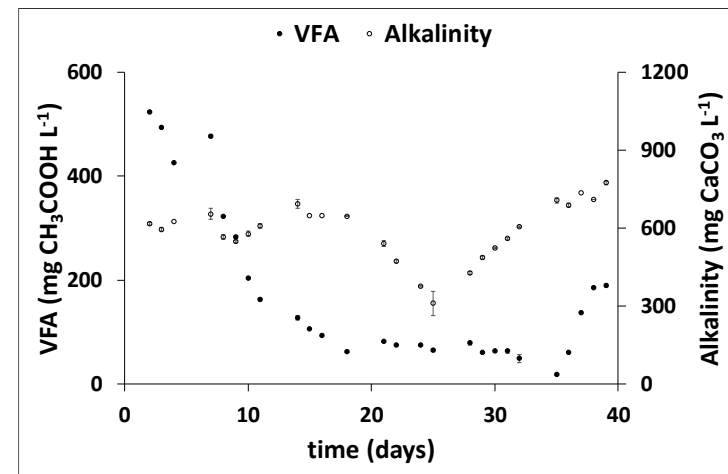

a)

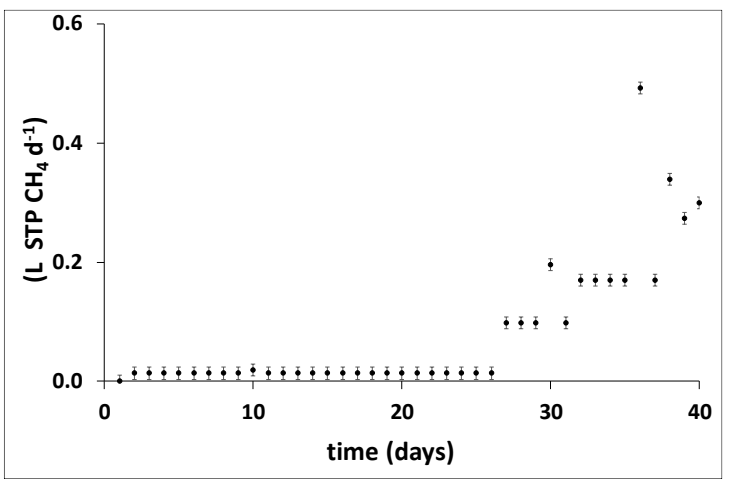

b)

Figure 3. Evolution over time during the rumen-like fermenter mode of: VFA and Alkalinity (a), and methane production (b). Error bars represent the standard deviations of the average values determined from three measurements (a), and the sensitivity of the measuring device (b).

Far less methane is generated from acetate in the rumen than in anaerobic digesters. This means that ruminants have a competitive edge over the methanogenic organisms that may appear in their own rumen because the production of methane entails a loss of potential energy (due to substrate absorption) for the animal [21]. In the present study, methane was generated in Run I with a retention time of 7 days $(\mathrm{HRT}=$ SRT) whilst the system was operating as a RF system. In this case, there is no animal to compete with so all the acetate is available for the methanogenic organisms. Therefore, to generate more methane, the RF system was converted into an anaerobic digester after a period of 40 days. These results highlight the great impact of hydrolysis on the anaerobic process, which influences the subsequent phases of anaerobic degradation and demonstrates that methanogenesis can take place when SRTs are as short as 7 days provided substrate is present.

\subsection{Run II: Anaerobic digestion of microalgae by rumen microorganisms.}

Impact of retention time on AnR and AnMBR performance. 
After inoculating the anaerobic reactor (AnR) with RF sludge, a retention time of 14 days $(\mathrm{HRT}=\mathrm{SRT})$ and an OLR of $0.4 \mathrm{~g} \mathrm{~L} \mathrm{day}^{-1}$ were set for the AnR for a period of 14 days (period II). In period III, the retention time was increased to 28 days (HRT = SRT) and the OLR was changed to $0.2 \mathrm{~g} \mathrm{~L} \mathrm{day}^{-1}$. This was followed by period IV which started with a UHF membrane being fitted to the system. The UHF membrane enabled all the biomass to be retained, disassociating SRT and HRT. As a result, HRT and OLR remained constant whereas SRT climbed from 28 to 70 days in period IV, and from 70 to 100 days in period V. Figure 4 shows the evolution of the main parameters over time.

The impact of SRT was evaluated by comparing periods II, III, IV and V, in which the SRT was increased step by step from 14 to 28,70 and 100 days, respectively. Figure 4a shows the evolution of T-COD and S-COD concentrations in the mixed liquor, and also the permeate COD concentrations (P-COD) whilst the system was operating as an AnMBR (periods IV and V). The T-COD fraction remained stable throughout Run II indicating that the solubilisation of particulate COD was higher when the SRT was higher. Particulate COD was not only solubilised, but also removed, as revealed by the low S-COD observed (see Figure 4a). This hypothesis is supported by the fact that daily methane production increased as SRT increased (Figure 4c). P-COD was similar to S-COD in every period studied, indicating that virtually no COD was retained by the membrane. Total suspended solids (TSS) followed the same trend as TCOD (Figure 4b) which also suggests that solubilisation was higher due to higher SRT. Total nitrogen (T-N) remained stable at around $450 \mathrm{mg} \mathrm{N} \mathrm{L}^{-1}$, higher than the $\mathrm{T}-\mathrm{N}$ in the microalgae biomass (370 $\left.\mathrm{mg} \mathrm{N} \mathrm{L}^{-1}\right)$. Ammonium nitrogen increased from around 198 $\mathrm{mg} \mathrm{L}^{-1}$ in period III to $258 \mathrm{mg} \mathrm{L}^{-1}$ in period IV and $284 \mathrm{mg} \mathrm{L}^{-1}$ in period V. Ammonium nitrogen content increased as the mineralisation of organic nitrogen increased during longer SRTs (Figure 3d). 


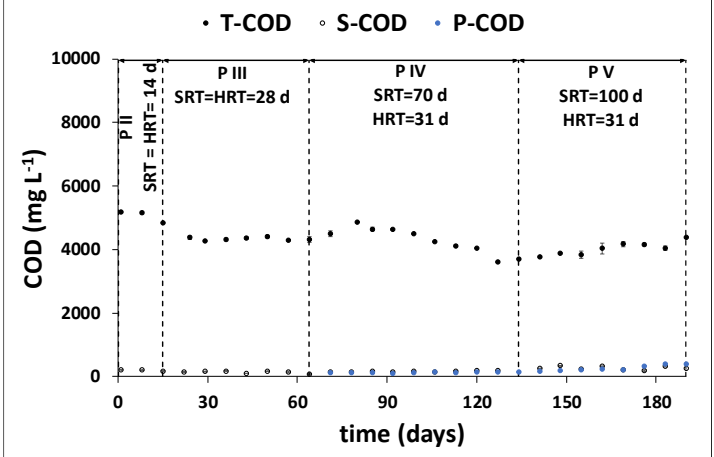

a)

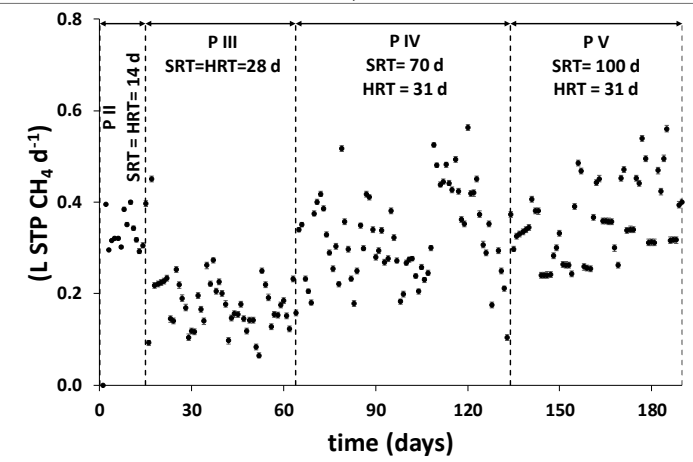

c)

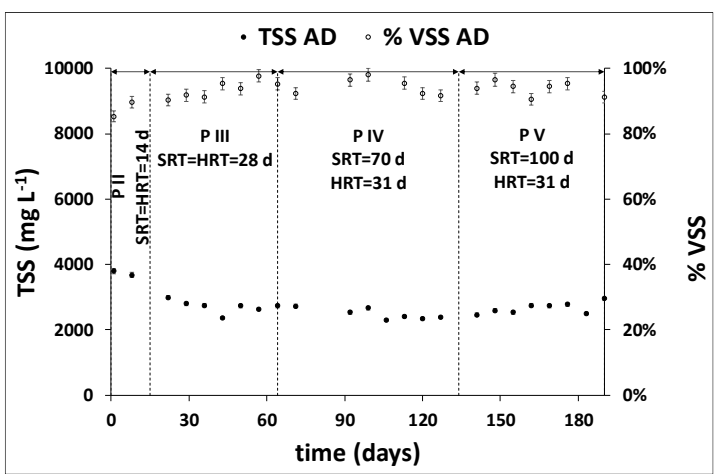

b)

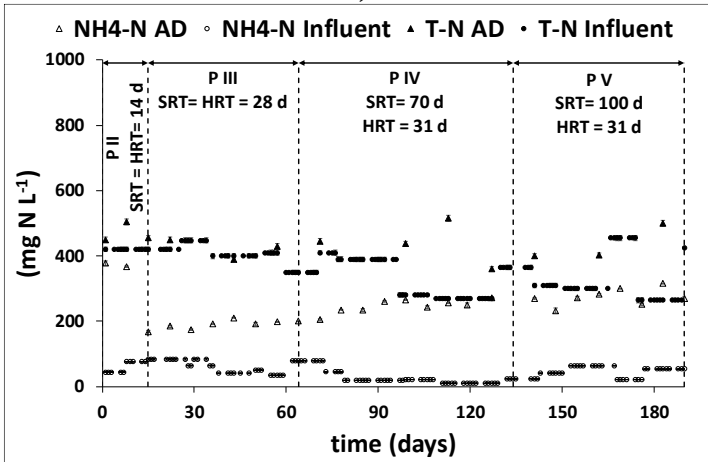

d)

Figure 4. Evolution over time during the anaerobic digester mode of: (a) T-COD, S-COD and P-COD, (b) TSS and \% VSS, (c) methane production, and (d) T-N and $\mathrm{NH}_{4}-\mathrm{N}$ in the influent and in the anaerobic digester (AD). Error bars represent the standard deviations of the average values determined from three measurements ( $a, b$ and $d$ ), and the sensitivity of the measuring device (c).

The steady-state of the effluents (sludge and permeate) in each period was characterised by negligible COD and TSS accumulation and stable daily methane production (Table 3).

Table 3. Steady-state characterisation of effluent streams (waste sludge \& permeate). Mean values \pm standard deviation of the temporal series for each period studied.

\begin{tabular}{|c|c|c|c|c|c|}
\hline \multirow{2}{*}{ Parameter } & \multirow{2}{*}{ Units } & \multicolumn{4}{|c|}{ Period } \\
\hline & & PII & PIII & $P I V$ & $P V$ \\
\hline \multirow{3}{*}{ TSS } & & $3740 \pm 85$ & $2697 \pm 58$ & $2380 \pm 36$ & $2738 \pm 165$ \\
\hline & $\mathrm{mg} \mathrm{TSS} \mathrm{L}^{-1}$ & $(\mathrm{n}=3)$ & $(\mathrm{n}=3)$ & $(\mathrm{n}=3)$ & $(\mathrm{n}=5)$ \\
\hline & & $87.4 \pm 3.1$ & $95.6 \pm 2.0$ & $93.1 \pm 2.0$ & $92.9 \pm 2.4$ \\
\hline$\% \mathrm{VSS}$ & $\%$ & $(\mathrm{n}=3)$ & $(n=3)$ & $(\mathrm{n}=3)$ & $(\mathrm{n}=5)$ \\
\hline $\mathrm{TS}$ & $\mathrm{mg} \mathrm{TS} \mathrm{L}^{-1}$ & $4508 \pm 192$ & $3723 \pm 20$ & $3371 \pm 61$ & $3746 \pm 104$ \\
\hline
\end{tabular}




\begin{tabular}{|c|c|c|c|c|c|}
\hline & & $(\mathrm{n}=3)$ & $(\mathrm{n}=3)$ & $(n=3)$ & $(\mathrm{n}=5)$ \\
\hline & & $74.9 \pm 0.9$ & $71.4 \pm 1.0$ & $69.8 \pm 1.5$ & $70.0 \pm 3.5$ \\
\hline \multirow[t]{2}{*}{$\% \mathrm{VS}$} & $\%$ & $(\mathrm{n}=3)$ & $(\mathrm{n}=3)$ & $(\mathrm{n}=3)$ & $(\mathrm{n}=5)$ \\
\hline & & $5058 \pm 190$ & $4332 \pm 48$ & $4130 \pm 105$ & $4188 \pm 229$ \\
\hline \multirow[t]{2}{*}{ T-COD } & $m g$ COD L $^{-1}$ & $(\mathrm{n}=3)$ & $(\mathrm{n}=7)$ & $(\mathrm{n}=3)$ & $(n=4)$ \\
\hline & & $196 \pm 18$ & $137 \pm 39$ & $164 \pm 16$ & $268 \pm 58$ \\
\hline \multirow[t]{2}{*}{ S-COD } & $m g$ COD L $^{-1}$ & $(n=3)$ & $(n=7)$ & $(n=3)$ & $(n=4)$ \\
\hline & & & & $132 \pm 13$ & $254 \pm 84$ \\
\hline \multirow[t]{2}{*}{ P-COD } & $m g \mathrm{COD} \mathrm{L}^{-1}$ & - & - & $(\mathrm{n}=3)$ & $(n=4)$ \\
\hline & & $455 \pm 18$ & $423 \pm 31$ & $439 \pm 63$ & $434 \pm 57$ \\
\hline \multirow[t]{2}{*}{$\mathrm{T}-\mathrm{N}$} & $m g \mathrm{~N} \mathrm{~L}^{-1}$ & $(\mathrm{n}=3)$ & $(\mathrm{n}=3)$ & $(n=4)$ & $(\mathrm{n}=3)$ \\
\hline & & $48.3 \pm 2.5$ & $39.4 \pm 7.7$ & $36.7 \pm 0.6$ & $29.3 \pm 1.1$ \\
\hline \multirow[t]{2}{*}{$\mathrm{T}-\mathrm{P}$} & $\mathrm{mg} \mathrm{P} \mathrm{L}^{-1}$ & $(\mathrm{n}=3)$ & $(\mathrm{n}=3)$ & $(\mathrm{n}=3)$ & $(\mathrm{n}=3)$ \\
\hline & & $169 \pm 8$ & $198 \pm 8$ & $258 \pm 10$ & $284 \pm 25$ \\
\hline \multirow[t]{2}{*}{$\mathrm{NH}_{4}-\mathrm{N}$} & $\mathrm{mg} \mathrm{N} \mathrm{L}^{-1}$ & $(\mathrm{n}=3)$ & $(\mathrm{n}=5)$ & $(\mathrm{n}=6)$ & $(\mathrm{n}=5)$ \\
\hline & & $14.3 \pm 1.1$ & $16.8 \pm 1.4$ & $13.3 \pm 2.5$ & $17.1 \pm 1.9$ \\
\hline \multirow[t]{2}{*}{$\mathrm{PO}_{4}-\mathrm{P}$} & $\mathrm{mg} \mathrm{PL}^{-1}$ & $(n=3)$ & $(\mathrm{n}=7)$ & $(\mathrm{n}=9)$ & $(\mathrm{n}=5)$ \\
\hline & & $3.9 \pm 0.5$ & $4.2 \pm 0.4$ & $4.1 \pm 1.0$ & $4.2 \pm 0.5$ \\
\hline $\mathrm{SO}_{4}-\mathrm{S}$ & $\mathrm{mg} \mathrm{S} \mathrm{L}^{-1}$ & $(\mathrm{n}=3)$ & $(n=7)$ & $(\mathrm{n}=9)$ & $(\mathrm{n}=5)$ \\
\hline
\end{tabular}

It is important to highlight that unlike T-N, the T-P content of the mixed liquor (42 $\mathrm{mg} \mathrm{P} \mathrm{L}^{-1}$ ) was lower than the T-P content of microalgae (66.7 $\left.\mathrm{mg} \mathrm{P} \mathrm{L}^{-1}\right)$. This suggests that chemical precipitation mechanisms were taking place within the system, giving rise to controversial results about the efficiency of phosphorus mineralisation (data not shown). Another noteworthy result shown in table 3 is the low sulphate 
content of the effluent, which indicates an almost complete reduction of sulphate to sulphide. During dissimilative sulphate reduction to sulphide, a fraction of the biodegradable COD is consumed by sulphate-reducing bacteria. According to Lens et

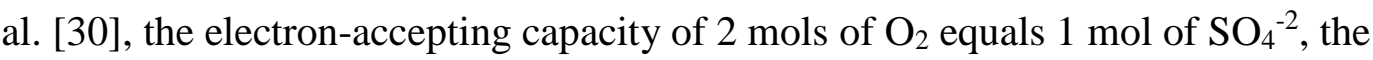
equivalent of $0.67 \mathrm{~g} \mathrm{COD} \mathrm{g}^{-1} \mathrm{SO}_{4}$. In this context, two different terms were used to distinguish between the biodegradable COD yielding methane (biomethane potential, BMP) and the biodegradable COD yielding the main reduced end-products of anaerobic digestion (biodegradation potential, BDP) under the specified operating conditions. Likewise, the COD consumed by dissimilative sulphate reduction was quantified in terms of methane, taking into account that $350 \mathrm{~mL}(\mathrm{STP})$ of $\mathrm{CH}_{4}$ can theoretically be produced per gram of anaerobically degraded COD (i.e. $234.5 \mathrm{~mL}$ (STP) $\mathrm{CH}_{4} \mathrm{~g}^{-1} \mathrm{SO}_{4}$ ). The resulting amount was used to quantify the methane + sulphide yield $\left(\mathrm{Y}^{\mathrm{CH}_{4}+\mathrm{H}_{2} \mathrm{~S}}\right)$.

Table 4. Microalgae biomass digestion performance under different operational conditions. Mean values \pm standard deviation of the steady-state for each period.

Parameter Units $\quad$ Period

$\begin{array}{cccc}\text { PII } & \text { PIII } & \text { PIV } & \text { PV } \\ (n=10) & (n=26) & (n=46) & (n=43)\end{array}$

\section{Operating conditions}

$\begin{array}{cccccc}\text { SRT } & \mathrm{d} & 14.0 & 28.1 \pm 0.7 & 67.8 \pm 7.3 & 95.5 \pm 16.0 \\ \mathrm{HRT} & \mathrm{d} & 14.0 & 28.1 \pm 0.7 & 34.6 \pm 11.9 & 30.1 \pm 6.5 \\ \mathrm{HLR} & \mathrm{g} \mathrm{COD} \mathrm{L} \mathrm{L}^{-1} & 0.40 \pm 0.07 & 0.20 \pm 0.01 & 0.20 \pm 0.01 & 0.19 \pm 0.02\end{array}$

Experimental results

$$
(n=3) \quad(n=4) \quad(n=4) \quad(n=3)
$$

$\begin{array}{lccccc}\text { COD Removal } & \% & 26.1 \pm 4.9 & 36.1 \pm 8.8 & 73.2 \pm 6.0 & 70.1 \pm 10.7 \\ \text { VSS }_{\text {Removal }} & \% & 25.6 \pm 13.4 & 43.4 \pm 5.2 & 77.3 \pm 13.8 & 68.1 \pm 10.8\end{array}$




\begin{tabular}{cccccc}
\hline WSP & mg VSS g ${ }^{-1} \mathrm{COD}_{\text {In }}$ & $501 \pm 6$ & $378 \pm 15$ & $168 \pm 11$ & $133 \pm 9$ \\
$\mathrm{Y}^{\mathrm{CH}_{4}}$ & $\mathrm{~mL} \mathrm{CH}_{4} \mathrm{~g}^{-1} \mathrm{COD}_{\text {In }}$ & $82 \pm 6$ & $102 \pm 26$ & $163 \pm 31$ & $203 \pm 15$ \\
$\mathrm{BMP}$ & $\%$ & $24.0 \pm 1.8$ & $29.8 \pm 4.4$ & $47.1 \pm 7.4$ & $58.7 \pm 4.4$ \\
$\mathrm{Y}^{\mathrm{CH}_{4}+\mathrm{H}_{2} \mathrm{~S}}$ & $\mathrm{~mL} \mathrm{CH}_{4} \mathrm{~g}^{-1} \mathrm{COD}_{\text {In }}$ & $90 \pm 2$ & $110 \pm 24$ & $175 \pm 32$ & $214 \pm 15$ \\
$\mathrm{Y}^{\mathrm{CH}_{4}+\mathrm{H}_{2} \mathrm{~S}}$ & $\mathrm{~mL} \mathrm{CH}_{4} \mathrm{~g}^{-1} \mathrm{VSS}_{\text {In }}$ & $144 \pm 2$ & $185 \pm 45$ & $278 \pm 43$ & $360 \pm 52$ \\
$\mathrm{BDP}$ & $\%$ & $26.0 \pm 0.9$ & $32.0 \pm 4.3$ & $50.5 \pm 7.6$ & $61.7 \pm 4.3$ \\
\hline
\end{tabular}

Table 4 shows the AD operating conditions and the steady-state performance results in each period. The COD removal and VSS removal rates were similar, which suggests that different components of microalgae cells were degraded homogeneously regardless of the SRT. According to Sialve et al. [6], the macromolecules that comprise microalgae (lipids, proteins and carbohydrates) have different COD/VS ratios $(2.90$, 2.43 and $1.19 \mathrm{~g} \mathrm{COD} \mathrm{g}^{-1} \mathrm{VS}$, respectively). It may therefore be assumed that the preferential degradation of one type of macromolecule would have led to different COD and VSS removal rates. The SRT obviously had an impact on both COD and VSS removal rates, as shown by the ANOVA results ( $\mathrm{p}$-values $=3.4410^{-6}$ and $1.6610^{-3}$, respectively). Fisher's LSD analysis stated that a significant increase in COD removal only occurred after SRT increased from 28 days (period III) to 70 days (period IV). As for the impact of SRT on COD removal efficiency, an increase from $26.1 \%$ to $36.1 \%$ was observed after SRT increased from 14 to 28 days. The addition of membranes made it possible to operate at higher SRTs, leading to a significant increase in COD removal: $73.2 \%$ after 70 days of SRT. However, this high value fell slightly to $70.1 \%$ when SRT was extended to 100 days. As mentioned earlier, the pattern of VSS removal efficiency was similar to that of COD removal. Significantly less sludge was generated when the SRT increased $\left(\mathrm{p}\right.$-value $\left.=1.0410^{-10}\right)$, falling from $0.501 \mathrm{mg} \mathrm{VSS} \mathrm{mg}^{-1} \mathrm{COD}_{\text {In }}$ after an 
SRT of 14 days to $0.133 \mathrm{mg}$ VSS $\mathrm{mg}^{-1} \mathrm{COD}_{\text {In }}$ after 100 days. Fisher's LSD analysis stated that significant differences existed between the mean WSPs of different periods. Lower WSP should have led to an increase in the particulate fractions (mainly T-COD, TSS, TS and T-N) in the reactor. However, particulate fractions remained constant throughout Run II, indicating greater biodegradability.

BDP was lower than COD and VSS removal rates after the membrane was fitted. This was attributed to bubbles of methane being discharged with the effluent. These bubbles were formed as a result of a drop in partial pressure on the vacuum side of the membrane, causing a decrease in the saturation level of the dissolved gases. Nevertheless, biodegradation potential increased significantly from $26.0 \%$ at a SRT of 14 days to $61.7 \%$ at a SRT of 100 days (p-value $=7.8310^{-6}$ ). Fisher's LSD analysis stated that significant differences existed among the mean BDPs of different periods, except for periods II (SRT $=14$ days) and III (SRT = 28 days $).$ BDP had a linear correlation in the range of SRT values under study, as shown by the high Pearson correlation-coefficient obtained for the least squares linear regression between BDP and SRT (see Figure 5). The $95 \%$ confidence bands (C.B.) and prediction bands (P.B.) have been calculated according to equations 3 and 4, respectively:

$$
\begin{aligned}
& \text { C.B. }(95 \%)=20.16+0.4214 * S R T \pm 5.138 * \sqrt{0.083+\left[\frac{S R T-53}{13947}\right]^{2}} \quad \text { Equation } 3 \\
& \text { P.B. }(95 \%)=20.16+0.4214 * S R T \pm 5.138 * \sqrt{1.083+\left[\frac{S R T-53}{13947}\right]^{2}} \quad \text { Equation } 4
\end{aligned}
$$




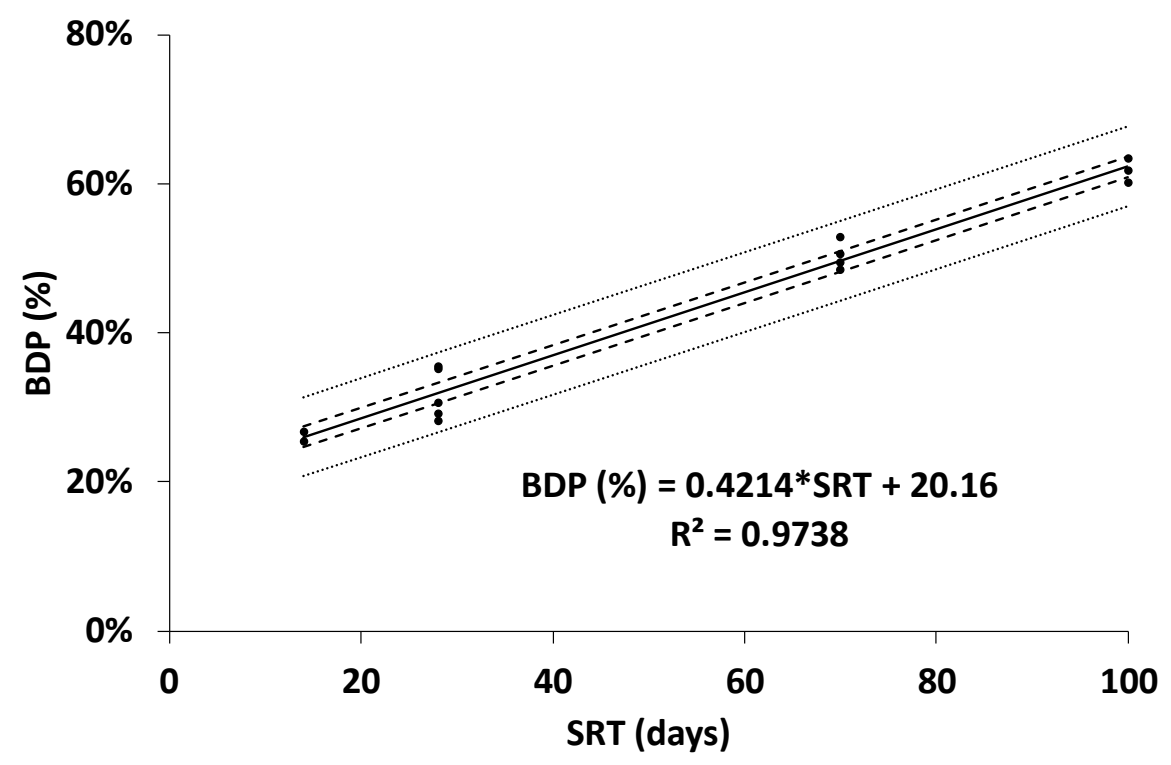

Figure 5. Linear regression between biodegradation potential (BDP) and sludge retention time (SRT). The dashed lines represent the $95 \%$ confidence bands. The dotted lines represent the $95 \%$ prediction bands.

Recent studies have evaluated the BDP of both raw and pre-treated Scenedesmus Spp biomass in batch tests lasting around 35 days. This is the case of Mussnug et al. [9] who performed a multi-strain biodegradation study in which Scenedesmus Obliquus fermentation was the least efficient and had a methane yield of $178 \mathrm{~mL} \mathrm{CH}_{4} \mathrm{~g}^{-1} \mathrm{VSS}_{\mathrm{IN}}$, similar to the $185 \mathrm{~mL} \mathrm{CH}_{4} \mathrm{~g}^{-1} \mathrm{VSS}_{\text {IN }}$ obtained after short SRTs (28 days) in this study. González-Fernández et al. [31] compared the effect of two different pre-treatment methods to improve the biodegradability of Scenedesmus Spp biomass (raw biomass $\left.81.8 \mathrm{~mL} \mathrm{CH}_{4} \mathrm{~g}^{-1} \mathrm{COD}_{\mathrm{IN}}\right)$. They obtained $128.7 \mathrm{~mL} \mathrm{CH}_{4} \mathrm{~g}^{-1} \mathrm{COD}_{\mathrm{IN}}$ after using thermal pre-treatment $\left(80^{\circ} \mathrm{C}\right)$ and $153.5 \mathrm{~mL} \mathrm{CH}_{4} \mathrm{~g}^{-1} \mathrm{COD}_{\text {IN }}$ after using ultrasounds (128.9 MJ $\mathrm{kg}^{-1}$ ) respectively. Mahdy et al. [32] compared the effect of low-temperature autohydrolysis $\left(50^{\circ} \mathrm{C}\right.$ for 24 and 48 hours) and thermoalkaline pre-treatments (autohydrolysis with w/w NaOH levels of $0.5-5 \%$ ) pre-treatments on the potential biodegradability of the Scenedesmus Spp biomass. Low-temperature autohydrolysis had no significant effect on the BDP of raw biomass, whilst thermoalkaline pre-treatment increased the methane yield by $20 \%$ up to $158 \mathrm{~mL} \mathrm{CH}_{4} \mathrm{~g}^{-1} \mathrm{COD}_{\mathrm{INF}}$, which is similar to the value reported by González-Fernández et al. [31], the equivalent of BDP of $45.0 \%$. 
The findings of these different studies lie within the range of 110 to $175 \mathrm{~mL} \mathrm{CH}_{4} \mathrm{~g}^{-1}$ COD INF obtained in the present study with SRTs of 28 and 70 days, respectively. Furthermore, no pre-treatment was performed prior to microalgae digestion in the present study, which makes the use of rumen microorganisms in microalgae digestion to produce biomethane a promising alternative to energy-intensive pre-treatment methods.

The results obtained in the present study indicated that using ruminal fluid as inoculum helped increase hydrolytic activity in the system. The methane yield was similar or higher (depending on the SRT chosen) than the yield in the abovementioned studies using different pre-treatment methods, which suggests that the cell wall was probably broken down. Even if the cell wall was broken down, it would in all likelihood not be degraded on account of its resilient nature. For this reason, the methane yield was still below the theoretical value estimated by Sialve et al. [6] for Scenedesmus Spp biomass based on its macromolecular composition (590-690 $\mathrm{mL} \mathrm{CH}_{4} \mathrm{~g}^{-1} \mathrm{VSS}$ ). Furthermore, the membranes retained the rumen microorganisms in the system and extended the contact time between the substrate (microalgae) and the microorganisms, resulting in a reasonable increase in the BDP of the microalgae Scenedesmus Spp in comparison with previous studies.

\section{CONCLUSIONS}

In the present work, a lab-scale digester treating Scenedesmus Spp with rumen microorganisms was successfully operated for 190 days. Initially, the system was operated in rumen-like fermenter mode for the pretreatment of microalgae. However, the absence of a competing animal enabled the methanogenic population to grow producing methane even for solid retention times as short as 7 days. In a second run, the system was operated in anaerobic digestion mode, both as an anaerobic reactor and anaerobic membrane bioreactor. Under this operating mode, the combination of an 
inoculum consisting of ruminal fluid and membranes helped increase the microalgae biodegradability, yielding as much methane as other literature references in which microalgae were pre-treated prior to being anaerobically digested, or even more. In this work, the higher the SRT, the higher the biodegradation potential and the lower the sludge production. Specifically, anaerobic biodegradability of more than $60 \%$ was achieved for a SRT of 100 days. Therefore, high COD and VSS removal when treating Scenedesmus Spp with rumen-derived microorganisms is possible without using any type of pre-treatment prior to microalgae digestion.

\section{ACKNOWLEDGEMENTS}

This work was supported by the Spanish Ministry of Economy and Competitiveness (MINECO, CTM2011-28595-C02-01 and CTM2011-28595-C02-02) jointly with the European Regional Development Fund (ERDF), which is gratefully acknowledged. The authors are thankful to Ion Pérez Baena (Universitat Politècnica de València, Institut de Ciència i Tecnología Animal) for kindly providing the ruminal fluid used in this study.

\section{REFERENCES}

[1] K.C. Tran, J.L. Mendoza Martin, S. Heaven, C.J. Banks, F.G. Acien Fernandez, E. Molina Grima, Cultivation and anaerobic digestion of Scenedesmus spp. grown in a pilot-scale open raceway, Algal Res. 5 (2014) 95-102. doi:10.1016/j.algal.2014.06.001.

[2] A. Anbalagan, S. Schwede, C.F. Lindberg, E. Nehrenheim, Influence of hydraulic retention time on indigenous microalgae and activated sludge process, Water Res. 91 (2016) 277-284. doi:10.1016/j.watres.2016.01.027.

[3] A. J. Ward, D.M. Lewis, F.B. Green, Anaerobic digestion of algae biomass: A review, Algal Res. 410389528 (2014) 1-11. doi:10.1016/j.algal.2014.02.001. 
[4] F. Ometto, G. Quiroga, P. Pavel, B. Jefferson, R. Villa, Impacts of microalgae pre-treatments for improved anaerobic digestion: Thermal treatment, thermal hydrolysis , ultrasound and enzymatic hydrolysis, 5 (2014). Water Res. 65 (2014) 350-361. doi:10.1016/j.watres.2014.07.040.

[5] Y. Chisti, Biodiesel from microalgae, Biotechnol. Adv. 25 (2007) 294-306. doi:10.1016/j.biotechadv.2007.02.001.

[6] B. Sialve, N. Bernet, O. Bernard, Anaerobic digestion of microalgae as a necessary step to make microalgal biodiesel sustainable, Biotechnol. Adv. 27 (2009) 409-416. doi:10.1016/j.biotechadv.2009.03.001.

[7] J. Singh, S. Gu, Commercialization potential of microalgae for biofuels production, Renew. Sustain. Energy Rev. 14 (2010) 2596-2610. doi:10.1016/j.rser.2010.06.014.

[8] E.A. Ehimen, Z.F. Sun, C.G. Carrington, E.J. Birch, J.J. Eaton-Rye, Anaerobic digestion of microalgae residues resulting from the biodiesel production process, Appl. Energy. 88 (2011) 3454-3463. doi:10.1016/j.apenergy.2010.10.020.

[9] J.H. Mussgnug, V. Klassen, a. Schlüter, O. Kruse, Microalgae as substrates for fermentative biogas production in a combined biorefinery concept, J. Biotechnol. 150 (2010) 51-56. doi:10.1016/j.jbiotec.2010.07.030.

[10] C. González-Fernández, B. Sialve, N. Bernet, J.P. Steyer, Effect of organic loading rate on anaerobic digestion of thermally pretreated Scenedesmus sp. biomass, Bioresour. Technol. 129 (2013) 219-223. doi:10.1016/j.biortech.2012.10.123.

[11] H. Carrere, G. Antonopoulou, R. Affes, F. Passos, A. Battimelli, G. Lyberatos, I. Ferrer, Review of feedstock pretreatment strategies for improved anaerobic digestion: From lab-scale research to full-scale application, Bioresour. Technol. 
199 (2016) 386-397. doi:10.1016/j.biortech.2015.09.007.

[12] F. Passos, I. Ferrer, Microalgae Conversion to Biogas: Thermal Pretreatment Contribution on Net Energy Production, Environ. Sci. Technol. 48 (2014) 71717178. doi:10.1021/es500982v.

[13] S. Schwede, Z.U. Rehman, M. Gerber, C. Theiss, R. Span, Effects of thermal pretreatment on anaerobic digestion of Nannochloropsis salina biomass, Bioresour. Technol. 143 (2013) 505-511. doi:10.1016/j.biortech.2013.06.043.

[14] A.K. Lee, D.M. Lewis, P.J. Ashman, Disruption of microalgal cells for the extraction of lipids for biofuels: Processes and specific energy requirements, Biomass and Bioenergy. 46 (2012) 89-101. doi:10.1016/j.biombioe.2012.06.034.

[15] L. Mendez, A. Mahdy, R.A. Timmers, M. Ballesteros, C. González-Fernández, Enhancing methane production of Chlorella vulgaris via thermochemical pretreatments, Bioresour. Technol. 149 (2013) 136-141. doi:10.1016/j.biortech.2013.08.136.

[16] F. Passos, E. Uggetti, H. Carrère, I. Ferrer, Pretreatment of microalgae to improve biogas production: a review, Bioresour. Technol. 172 (2014) 403-412. doi:10.1016/j.biortech.2014.08.114.

[17] E.A. Ehimen, J.B. Holm-Nielsen, M. Poulsen, J.E. Boelsmand, Influence of different pre-treatment routes on the anaerobic digestion of a filamentous algae, Renew. Energy. 50 (2013) 476-480. doi:10.1016/j.renene.2012.06.064.

[18] G. Ciudad, O. Rubilar, L. Azócar, C. Toro, M. Cea, Á. Torres, A. Ribera, R. Navia, Performance of an enzymatic extract in Botrycoccus braunii cell wall disruption, J. Biosci. Bioeng. 117 (2014) 75-80. doi:10.1016/j.jbiosc.2013.06.012.

[19] H. Miao, M. Lu, M. Zhao, Z. Huang, H. Ren, Q. Yan, W. Ruan, Enhancement of 
Taihu blue algae anaerobic digestion efficiency by natural storage, Bioresour. Technol. 149 (2013) 359-366. doi:10.1016/j.biortech.2013.09.071.

[20] A. Ahamed, P. Vermette, Culture-based strategies to enhance cellulase enzyme production from Trichoderma reesei RUT-C30 in bioreactor culture conditions, Biochem. Eng. J. 40 (2008) 399-407. doi:10.1016/j.bej.2007.11.030.

[21] H.J. Gijzen, Anaerobic digestion of cellulosic waste by rumen-derived process, PhD Thesis, Nijmegen University, 1987.

[22] Z.H. Hu, H.Q. Yu, Application of rumen microorganisms for enhanced anaerobic fermentation of corn stover, Process Biochem. 40 (2005) 2371-2377. doi:10.1016/j.procbio.2004.09.021.

[23] S.P. Barnes, J. Keller, Anaerobic rumen SBR for degradation of cellulosic material., Water Sci. Technol. 50 (2004) 305-11.

[24] Z. Yue, H. Yu, H. Harada, Y. Li, Optimization of anaerobic acidogenesis of an aquatic plant, Canna indica L., by rumen cultures, Water Res. 41 (2007) 23612370. doi:10.1016/j.watres.2007.02.031.

[25] Z.B. Yue, W.W. Li, H.Q. Yu, Application of rumen microorganisms for anaerobic bioconversion of lignocellulosic biomass, Bioresour. Technol. 128 (2013) 738-744. doi:10.1016/j.biortech.2012.11.073.

[26] J.B. Giménez, A. Robles, L. Carretero, F. Durán, M. V Ruano, M.N. Gatti, J. Ribes, J. Ferrer, A. Seco, Experimental study of the anaerobic urban wastewater treatment in a submerged hollow-fibre membrane bioreactor at pilot scale., Bioresour. Technol. 102 (2011) 8799-806. doi:10.1016/j.biortech.2011.07.014.

[27] A.D. Eaton, L.S. Clesceri, E.W. Rice, A.E. Greenberg, eds., Standard methods for the examination of water \& wastewater, 21st ed., Ammerican Public Health Association, Washington, 2005. 
[28] G.A.E. and G.M. R.E. Moosbrugger, M.C. Wentzel, Simple titration procedures to determine $\mathrm{H}_{2} \mathrm{CO}_{3}$ alkalinity and short-chain fatty acids in aqueous solutions containing known concentrations of ammonium, phosphate and sulphide weak acid/bases, 1992.

[29] F. Raposo, V. Fernández-Cegrí, M.A. de la Rubia, R. Borja, F. Béline, C. Cavinato, G. Demirer, B. Fernández, M. Fernández-Polanco, J.C. Frigon, R. Ganesh, P. Kaparaju, J. Koubova, R. Méndez, G. Menin, A. Peene, P. Scherer, M. Torrijos, H. Uellendahl, I. Wierinck, V. de Wilde, Biochemical methane potential (BMP) of solid organic substrates: Evaluation of anaerobic biodegradability using data from an international interlaboratory study, J. Chem. Technol. Biotechnol. 86 (2011) 1088-1098. doi:10.1002/jctb.2622.

[30] P.N.L. Lens, A. Visser, A.J.H. Janssen, L.W.H. Pol, G. Lettinga, Critical Reviews in Environmental Science and Technology Biotechnological Treatment of Sulfate-Rich Wastewaters Biotechnological Treatment of Sulfate-Rich Wastewaters, Critical Reviews in Environmental Science and Technology. 28:1 81998) 41-88.

[31] C. González-Fernández, B. Sialve, N. Bernet, J.P. Steyer, Thermal pretreatment to improve methane production of Scenedesmus biomass, Biomass and Bioenergy. 40 (2012) 105-111. doi:10.1016/j.biombioe.2012.02.008.

[32] A. Mahdy, L. Mendez, M. Ballesteros, C. González-Fernández, Autohydrolysis and alkaline pretreatment effect on Chlorella vulgaris and Scenedesmus sp. methane production, Energy. 78 (2014) 48-52. doi:10.1016/j.energy.2014.05.052. 